\title{
Petrology and U-Pb-Lu-Hf zircon isotopes of mafic to hybrid synplutonic dykes from Ladakh Batholith, Trans Himalaya, India
}

\author{
SANTOSH KUMAR ${ }^{1}$, KAPIL S PANWAR ${ }^{1}$, KEEWOOK YI ${ }^{2}$, \\ YOUN-JOONG JEONG ${ }^{2}$, SUBHRANSU PANI ${ }^{1}$ AND UMESH \\ K SHARMA $^{3}$ \\ ${ }^{1}$ Kumaun University \\ ${ }^{2}$ Korea Basic Science Institute \\ ${ }^{3}$ Department of Science and Technology \\ Presenting Author: skyadavan@yahoo.com
}

Fine grained (mafic) to porphyritic (hybrid) composite and brecciated synplutonic dykes intrude the granites (sensu lato) of Ladakh Batholith, Trans Himalaya, India. Field and microstructural features strongly suggest injection of mafic to hybrid magmas into the mostly crystallized $(>65 \%)$ host granite magma $[1,2]$. They commonly have sharp and pillow-like contacts with host granites, and disrupted to form platy, rounded, elliptical and brecciated enclave swarms, which are broadly oriented in the dyke strike direction. The synplutonic hybrid dykes contain felsic xenocrysts that are sourced and injected from hybrid zone hidden at depth. The host granite shows medium to coarse grained equigranular textures. Mafic to hybrid synplutonic dykes bear hbl-bt-pl-Kf-qz-mag-zrn assemblage similar to host granite, and differ in mineral proportion. Biotite from the dykes and host granite represents $\mathrm{Mg}$ - and $\mathrm{Fe}$ - biotites and moderately reduced (FMQ) to strongly oxidized (NNO), typically crystallizing in a metaluminous (I-type) calc alkaline host magma. However, biotite from granite hosting the brecciated dyke contains higher $\mathrm{FeO}^{\mathrm{t}}$ and $\mathrm{Al}_{\text {apfu }}$ than others. Alin-amphibole rims suggest subvolcanic levels (75-135 MPa) of mafic to hybrid dykes and host granite emplacement whereas brecciated dyke solidified at relatively deeper crustal levels (250$360 \mathrm{MPa}$ ). SHRIMP analyzed zircons provide similar weighted mean ${ }^{206} \mathrm{~Pb} /{ }^{238} \mathrm{U}$ ages of mafic $(57.61 \pm 0.67 \mathrm{Ma})$, hybrid $(57.08 \pm 0.45 \mathrm{Ma})$ dykes and host granite $(57.19 \pm 0.38 \mathrm{Ma})$ that strongly underline their coeval nature. Brecciated dyke did not yield zircons and chemically bears signature of arc basalt whereas other mafic to hybrid dykes represent basaltic andesite. Zircon $\varepsilon \mathrm{Hf}^{\mathrm{t}}$ values of mafic $(+2.7$ to +25.19$)$, hybrid $(+8.48$ to $+18.08)$ dykes and host granite $(+3.27$ to +15.16$)$ indicate involvement of dominant juvenile sources. Whole rock elemental geochemistry of dykes and host granites are typical to calcalkaline subduction zone magmatism. However, they exhibit strong signatures of synchronous mixing, mingling, fractionation and diffusion processes.

[1] Kumar, S. (2010) Journal of Geological Society of India, $76,5-25$

[2] Kumar, S. (2020) Frontiers in Earth Science, 8, 551097 